\title{
EVALUATION OF THE EFFECT OF SINGLE NUCLEOTIDE POLYMORPHISM 1772C > T IN HIF- $\alpha$ GENE ON THE RESIDUAL RIDGE RESORPTION OF THE MANDIBLE IN THE EGYPTIAN POPULATION
}

\author{
Samar M. Emam¹ BDS, Noha M. Issa ${ }^{2} P h D$, Mohamed S. El-Attar ${ }^{3} P h D$
}

\begin{abstract}
INTRODUCTION: Atrophic residual ridges have always been an obstacle for a successful prosthodontics treatment. Residual ridge resorption (RRR) was attributed to a combination of anatomical, metabolic and mechanical determinants. Lately, the genetic factor was considered since single nucleotide polymorphisms (SNPs) in relevant genes have been present in patients having severe RRR.

OBJECTIVES: The aim of the current study was to investigate for the first time the relation between SNP 1772C > T in Hypoxia Inducible Factor-1 alpha (HIF-1 $\alpha$ ) gene and the presence of severely resorbed edentulous mandibular ridges in a sample of the Egyptian population.

MATERIALS AND METHODS: The study was conducted on 50 subjects divided into case and control groups according to the residual ridge height. Saliva was used as a convenient source of DNA in the dental clinic. PCR-Restriction Fragment Length Polymorphism was performed for genotyping.

RESULTS: A statistically significant difference in the distribution of the TT genotype between both groups was present. There was also a difference in the distribution of the CC and CT genotypes but it wasn't statistically significant. The T alleles were more abundant in the case group while the control group showed more frequency of the $C$ allele with no statistical significance.

CONCLUSIONS: This study concluded that the TT genotype of the 1772C $>\mathrm{T}$ polymorphism of HIF-1 $\alpha$ gene is related to the presence of severely atrophied residual ridges. This SNP can be used as a marker to predict the future condition of the ridge using saliva samples. Further studies on larger scale are recommended.
\end{abstract}

KEYWORDS: Edentulous mandible, Genetics, Hypoxia inducible factor-1 alpha (HIF1- $\alpha$ ), Residual ridge resorption (RRR), Single nucleotide polymorphisms (SNPs)

1- Dentist at the Alexandria University Students’ clinic, Alexandria University, Alexandria, Egypt.

2- Lecturer of Human Genetics, Medical Research Institute, Alexandria University, Alexandria, Egypt.

3- Professor of Prosthodontics, Faculty of Dentistry, Alexandria University, Alexandria, Egypt

Corresponding author:

E-mail: omarnour12@hotmail.com

\section{INTRODUCTION}

The term "residual ridge" is used to describe the clinical alveolar ridge formed as a consequence of wound healing after tooth extraction $(1,2)$. In prosthetic treatment, preservation of the residual ridge is essential for a successful outcome. Edentulous patients with severe ridge resorption might suffer from poorly fitting dentures and even implant failure in severe cases (3).

Immediately following tooth extraction, a cascade of inflammatory mediators is initiated, which results in the formation of a blood clot which is then gradually replaced by granulation tissue. Later, new bone formation is evident, with osteoid matrix undergoing mineralization in a coronal direction and two-thirds of the socket is filled in approximately 5 to 6 weeks (4). The most striking feature of the extraction wound healing is that even after the healing of wounds, the residual ridge alveolar bone undergoes a lifelong catabolic remodeling resulting in residual ridge resorption (5).

The pathogenesis of the residual ridge resorption is not well understood. It is assumed that the degree of reduction results from a combination of anatomical, metabolic and mechanical determinants (6). Since the residual ridge is primarily composed of unique oral soft tissue and alveolar bone formed as a result of tooth extraction wound healing, defects in socket matrix formation or cellular activity will lead to stalled healing. Therefore, potential genetic regulatory factors affecting the quality and quantity of bone altering the gene expression can result in RRR (5).

Once a tooth is extracted, blood vessels in the extraction socket get injured, blood supply is blocked and the oxygen pressure of the surrounding area decreases, which makes a state of hypoxia within the tissue (7). Hypoxia Inducible Factor-1 is a transcriptional complex that plays an important role in cellular and systemic oxygen homeostasis. It is the master regulator of oxygen-dependent genes and $60 \mathrm{HIF}-1$ target genes are known $(8,9)$. HIF-1 consists of $\alpha$ and $\beta$ subunits. The alpha subunit which determines HIF-1 activity is regulated by oxygen tension (10). Since HIF-1 $\alpha$ gene is very critical for oral wound healing after extraction of teeth, and since it has a high genetic diversity, common SNPs in HIF- $1 \alpha$ could have a role in the appearance of severely resorbed mandibular ridges (8).

SNP $1772 \mathrm{C}>\mathrm{T}$ is one of the two common HIF-1 $\alpha$ mutations. It is a coding SNP located in the ODD domain of exon 12 in HIF-1 $\alpha$ gene leading to an amino acid change from Proline 582 to Serine (8). This SNP was extensively studied trying to conclude its correlation with various types of cancer, ischeamic heart disease, osteonecrosis, chronic obstuctive pulmunary disease, diabetes and even to find out a genetic etiology for the high performance of elite athletes in poweroriented sports (11-17). 
The aim of the present study was to find out for the first time the correlation between SNP 1772C $>\mathrm{T}$ in HIF-1 $\alpha$ gene and the etiology of residual ridge resorption in the Egyptian population. This can be used as a marker to predict the future condition of the alveolar ridge before prosthodontic treatment through a simple test based on a saliva sample that can be easily collected in the dental clinic.

\section{MATERIALS AND METHODS}

\section{Ethical considerations}

The study was conducted after receiving the approval of the ethical committee of the Faculty of Dentistry, Alexandria University, Egypt.

\section{Study population}

This study is a case-control retrospective clinical study studying the relation between SNP $1772 \mathrm{C}>\mathrm{T}$ in the HIF-1 $\alpha$ gene and the residual ridge resorption. The study population consisted of Egyptian male and female completely edentulous patients. Their age range was between 40 to 70 years old. Patients were free from any systemic disease that could adversely affect bone condition, such as diabetes, disturbances in thyroid metabolism and osteoporosis. They also didn't have a history of alveolar bone augmentation.

\section{Sample size}

A sample of 50 patients divided into 2 groups is required to estimate an average $1772 \mathrm{C}>\mathrm{T}$ SNP in HIF-1 $\alpha$ gene $=11.9$ using alpha error $=0.05$ providing a study power of $80 \%$. The sample size was calculated using Epi-Info 7 software (18). The sample was selected randomly using simple random sample technique from the patients -meeting the previously mentioned requirements- visiting the prosthodontics department clinic, faculty of dentistry, Alexandria University.

\section{Patients groups}

A detailed personal, medical and dental history was taken from the patients. The alveolar ridge condition and height was examined clinically and with digital panoramic radiographs and the selected patients were divided into 2 groups:

- Group A: Patients having mandibular residual ridge showing severe resorption.

- Group B: Patients having a well-developed mandibular residual ridge showing no or minimal resorption. (Figure 1)
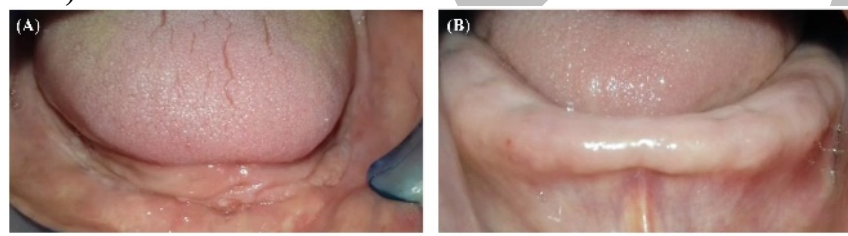

Figure (1): Clinical presentation of edentulous patients.

The least vertical height of the edentulous mandible was measured in the panoramic radiographs following the protocol of the American College of Prosthodontics (ACP) (19). The Prosthodontic Diagnosis Index Classification (ACP classification) is as follows:

- Type I: residual ridge bone height of $21 \mathrm{~mm}$ or greater.

- Type II: residual ridge bone height of 16 to $20 \mathrm{~mm}$.

- Type III: residual ridge bone height of 11 to $15 \mathrm{~mm}$.

- Type IV: residual ridge bone height of $10 \mathrm{~mm}$ or less.

Type III \& IV patients with severely resorbed mandibular ridges were considered group A (case) while type I \& II patients with well-developed mandibular ridges were considered group B (control). (Figure 2)
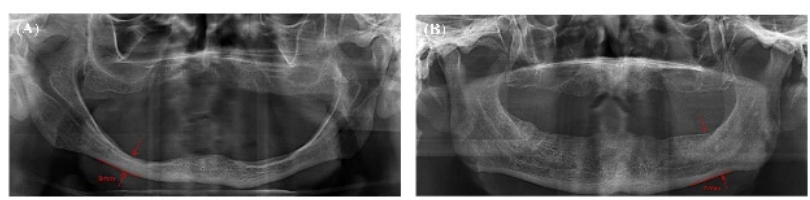

Figure (2): Radiographic presentation of edentulous patients.

\section{Collection of the saliva samples}

Saliva collection presents an easy non-invasive source of DNA in the dental clinic. Patients were advised to avoid food or drinks for 30 minutes. A $2 \mathrm{ml}$ saliva sample was then collected from each patient by passive drooling technique using sterile polypropylene tubes. Saliva was collected in either type of the following tubes:

1. Oragene.DNA ${ }^{\circledR}$ self-collecting kits (OG500 tubes): The patients were asked to collect $2 \mathrm{ml}$ of pure saliva not mixed with sputum. These tubes present the best way to collect saliva samples since they are provided with a lid containing $2 \mathrm{ml}$ of DNA preserving solution. With closure of the lid, the liquid in it was released in the tube to mix with the saliva. The $4 \mathrm{ml}$ sample can be safely stored at room temperature for a long time till further analysis. It can be easily sent to the Molecular Biology Lab by ordinary mail simplifying the transportation process (20). However, the price of the OG500 tubes in developing countries like Egypt is extremely expensive limiting their usage.

2. Sterile polypropylene tubes containing no preservatives presented an alternative way to collect saliva samples. Their economic price made them more practical to be used. Since saliva can be refrigerated or even frozen safely without compromising its properties or its DNA content (21), Corning ${ }^{\circledR}$ \& Cellstar ${ }^{\circledR}$ tubes were used to collect most saliva samples in this study. The lid of each tube was tightly closed and the samples were delivered by hand refrigerated in an ice box to the Molecular Biology Lab.

\section{Genomic DNA extraction}

Saliva samples were transported to the Molecular Biology Lab of the Human Genetics Department, Medical Research Institute, Alexandria University. Saliva provided a great number of nucleated cells such as epithelial cells, leukocytes and Langerhans cells (22). In this study, we used the QIAamp $^{\circledR}$ DNA Blood Mini Kit $\left(\right.$ QIAGEN $\left.^{\circledR}\right)$, vacuum procedure. Although it was originally designed to extract DNA from blood, it was found that it is successful in purifying up to $12 \mu \mathrm{g}$ genomic DNA from other body fluids -such as saliva- with complete removal of contaminants and inhibitors for reliable results. QIAGEN supplementary protocol was followed to extract a final higher DNA concentration from each saliva sample ready for RFLP applications. This procedure typically yields samples of 5-15 $\mu \mathrm{g}$ DNA with $\mathrm{A}_{260} / \mathrm{A}_{280}$ ratios of 1.7- 1.9 (23).

\section{PCR-RFLP analysis}

Primers design and selection of the restriction enzyme The human HIF-1 $\alpha$ gene, which is located at chromosome 14 (14q21-q24), is composed of 15 exons. The SNP 1772C>T is located in the coding region of the gene, in exon 12. In this study, the primers used for the exon 12 region were the following: forward 5' -GCT GAA GAC ACA GAA GCA AAG AAC-3', reverse 5'-GGG TAG GAG ATG GAG ATG 
CAA TCA-3’. For a reliable digestion of PCR products, the restriction enzyme HphI (Thermo Fisher Scientific inc.) was selected.

\section{PCR amplification of DNA samples}

This step was carried out in the Molecular Biology Lab of the Human Genetics Department, Medical Research Institute, Alexandria University. PCR conditions were: denaturation at $95^{\circ} \mathrm{C}$ for $4 \mathrm{~min}$, followed by 30 cycles of denaturation at $95^{\circ} \mathrm{C}$ for $30 \mathrm{sec}$, annealing and extension for exon 12 : $57^{\circ} \mathrm{C}$ for $2 \mathrm{~min}$ and $72^{\circ} \mathrm{C}$ for $30 \mathrm{sec}$, followed by a final extension step at $72^{\circ} \mathrm{C}$ for $10 \mathrm{~min}$. Agarose gel electrophoresis was used for size separation of the PCR products. The expected size of the amplified product is observed on the gel by comparing with an optimal DNA size marker (Themo Scientific GeneRuler 100 bp DNA ladder).

\section{Restriction enzyme digestion of PCR products}

PCR products were digested with the $\mathrm{HphI}$ restriction enzyme -following the manufacturer's instructions- at $37^{\circ} \mathrm{C}$ for overnight. They were then subjected to $2 \%$ agarose electrophoresis and stained for visualization of the PCRRFLP patterns. Variations in the length of the amplified DNA fragment indicate the presence of a SNP.

\section{Statistical analysis}

Statistical significance was evaluated by the Chi-square test and Fisher Exact test. The $p$-values equal to or smaller than 0.05 were regarded as statistically significant. The strength of association was estimated by the odds ratio (OR) and their 95\% confidence intervals (CI) were calculated (24). All statistics were calculated using the Statistical Package for Social Science (SPSS) software version 20.0. (Armonk, NY: IBM Corp) (25).

\section{RESULTS}

The present study was conducted on fifty completely edentulous healthy male and female Egyptian individuals. Their age range was between 40 and 70 years old. They didn't have a history of diseases affecting bone metabolism such as diabetes and thyroid gland diseases. They were divided into 2 groups according to their mandibular residual ridge bone height, following the protocol of the ACP (19). (Table 1)

Table (1): Comparison between the studied groups according to demographic data.

\begin{tabular}{|c|c|c|c|c|}
\hline & \multicolumn{2}{|c|}{$\begin{array}{l}\text { Patient } \\
(\mathrm{n}=25)\end{array}$} & \multicolumn{2}{|c|}{$\begin{array}{l}\text { Control } \\
(n=25)\end{array}$} \\
\hline & No. & $\%$ & No. & $\%$ \\
\hline $\begin{array}{l}\text { Age (years) } \\
\text { Range }\end{array}$ & \multicolumn{2}{|c|}{$42-70$} & \multicolumn{2}{|c|}{$50-70$} \\
\hline $\begin{array}{l}\text { Male } \\
\text { Mex } \\
\text { Female }\end{array}$ & $\begin{array}{c}17 \\
8 \\
\end{array}$ & $\begin{array}{l}68.0 \\
32.0 \\
\end{array}$ & $\begin{array}{c}19 \\
6\end{array}$ & $\begin{array}{l}76.0 \\
24.0\end{array}$ \\
\hline $\begin{array}{r}\begin{array}{r}\text { Bone height } \\
(\mathbf{m m})\end{array} \\
\text { Range } \\
\text { Mean }\end{array}$ & \multicolumn{2}{|c|}{$\begin{array}{c}8-15 \\
11.5\end{array}$} & \multicolumn{2}{|c|}{$\begin{array}{c}16-27 \\
21.5 \\
\end{array}$} \\
\hline
\end{tabular}

RFLP results shown on $2 \%$ agarose gel electrophoresis demonstrated that the $\mathrm{C}$ allele yielded two bands (at 251 and 216 bp) while the $\mathrm{T}$ allele remained uncut and yielded one fragment (at $467 \mathrm{bp}$ ). Therefore, the heterozygous genotype CT yielded three bands at 216, 251 and $467 \mathrm{bp}$; the homozygous genotype CC yielded two bands at 216 and 251 bp; the homozygous genotype TT yielded one uncut fragment at467 bp. Molecular weight standards -DNA ladder- were used for comparison. (Figure 3)

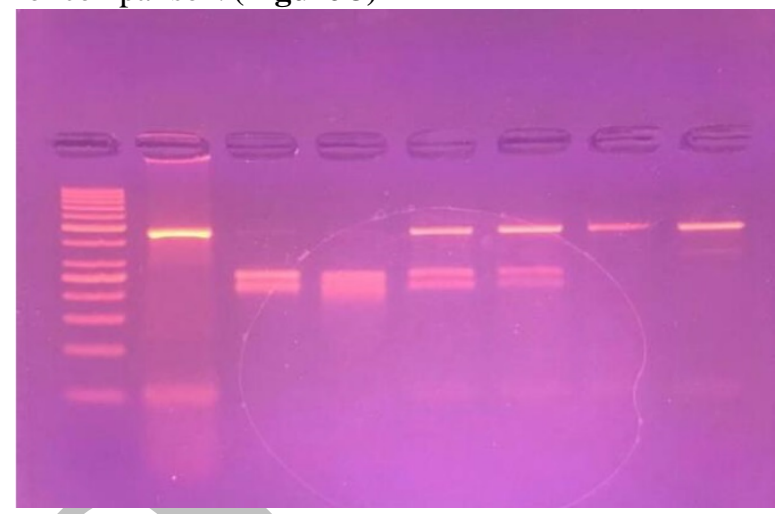

Figure 3: Restriction digestion of PCR products of HIF-1 $\alpha$ gene, 1772C $>\mathrm{T}$ polymorphism, using $\mathrm{HphI}$ enzyme resolved on $2 \%$ agarose gel. Lane I shows molecular weight marker (50 bp DNA ladder), lane II shows one bright band at 467 bp representing PCR products of HIF- $1 \alpha$ gene, lanes III \& IV show two bands at 251 and 216 bp representing CC genotype, lanes V \& VI show three bands at 467, 251and 216 representing CT genotype and the last lanes VII \& VIII show one band at 467 bp representing TT genotype.

Out of the 25 patients showing severe RRR -group A (case)- 5 cases (20\%) were of the genotype CC, 13 cases (52\%) were CT and 7 (28\%) were homozygous for the rare allele, showing the genotype TT. On the other hand, the genotype distribution of group B (control) showed that, out of 25 individuals with a well-developed RR, 6 controls (24\%) were of the homozygous genotype CC, 18 controls (72\%) were heterozygous having the genotype CT and only 1 control (4\%) was homozygous for the rare allele having the genotype TT. (Figure 4) The allele frequencies in the case patients were $23 \mathrm{C}(46 \%)$ and $27 \mathrm{~T}$ (54\%). While the allele frequencies in the control individuals were $30 \mathrm{C}$ (60\%) and $20 \mathrm{~T}$ (40\%). (Figure 5)

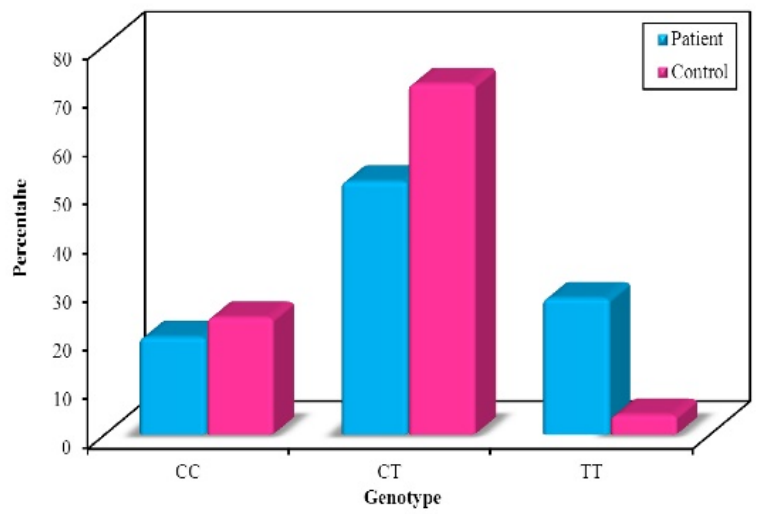

Figure 4: Comparison between the two studied groups according to genotype.

Statistical analysis showed no significant variation in the distribution of genotypes CC and CT among the case and control groups. The $p$-values for both CC and CT genotypes were 0.733 and 0.145 respectively. Meanwhile, statistical analysis showed that the distribution of the genotype TT in group A (case) differed significantly from that of group B (control). Comparing both groups, the $p$-value was 0.049 ( $\leq$ 0.05), suggesting that there is an association between SNP $1772 \mathrm{C}>\mathrm{T}$ in HIF-1 $\alpha$ gene and residual ridge resorption in the mandible of Egyptian completely edentulous patients 
having the genotype TT, showing the homozygous form of the rare allele $\mathrm{T}$. Regarding the distribution of $\mathrm{C}$ and $\mathrm{T}$ alleles individually between both groups, $p$-value was 0.161 . This means the distribution of the single allele $\mathrm{C}$ or $\mathrm{T}$ didn't differ significantly between both groups. (Table 2)

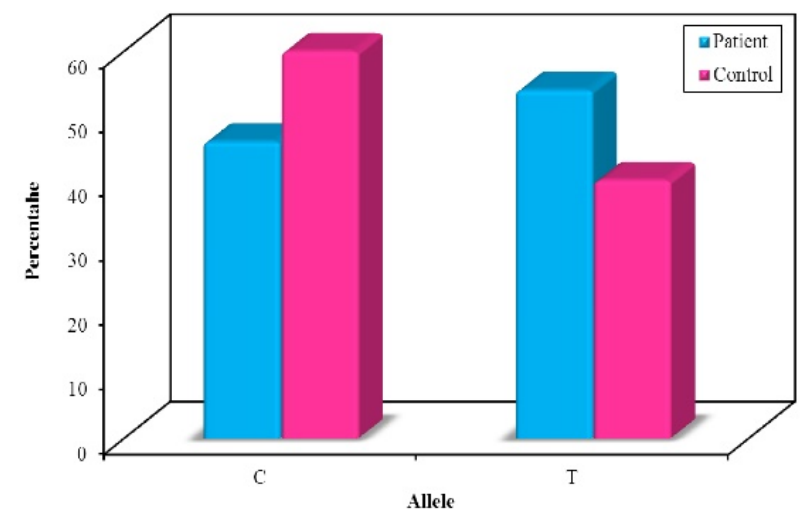

Figure 5: Comparison between the two studied groups according to allele.

Table (2): Comparison between the two studied groups according to genotype.

\begin{tabular}{|c|c|c|c|c|c|c|c|c|}
\hline & \multicolumn{2}{|c|}{$\begin{array}{c}\text { Patient } \\
(\mathbf{n}= \\
25)\end{array}$} & \multicolumn{2}{|c|}{$\begin{array}{l}\text { Control } \\
(n=25)\end{array}$} & \multirow[t]{2}{*}{$\chi^{2}$} & \multirow[t]{2}{*}{$\mathbf{p}$} & \multirow[t]{2}{*}{ OR } & \multirow{2}{*}{$\begin{array}{c}\text { 95\% C.I } \\
\text { (L.L - } \\
\text { U.L) }\end{array}$} \\
\hline & \begin{tabular}{|l|}
$\mathbf{N}$ \\
$\mathbf{o .}$ \\
\end{tabular} & $\%$ & No. & $\%$ & & & & \\
\hline $\begin{array}{l}\text { Genotype } \\
\text { CC }\end{array}$ & 5 & $\begin{array}{l}20 . \\
0 .\end{array}$ & 6 & 24. & 0.117 & 0.733 & 0.792 & $0.21-$ \\
\hline CT & 13 & $\begin{array}{l}52 . \\
0\end{array}$ & 18 & $\begin{array}{l}72 . \\
0\end{array}$ & 2.122 & 0.145 & 0.421 & $\begin{array}{l}0.13- \\
1.36\end{array}$ \\
\hline TT & 7 & \begin{tabular}{|l}
28. \\
0
\end{tabular} & 1 & 4.0 & 5.357 & $\begin{array}{l}{ }^{\mathrm{FE}} \mathrm{p}=0 . \\
049^{*}\end{array}$ & 9.333 & $\begin{array}{l}1.05- \\
82.78\end{array}$ \\
\hline $\begin{array}{l}\mathrm{CC}+ \\
\mathrm{CT}\end{array}$ & 18 & $\begin{array}{l}72 . \\
0\end{array}$ & 24 & $\begin{array}{l}96 . \\
0\end{array}$ & 5.357 & ${ }^{\mathrm{FE}} \mathrm{p}=$ & 0.107 & $\begin{array}{l}0.01- \\
0.95\end{array}$ \\
\hline TT & 7 & $\begin{array}{l}28 . \\
0\end{array}$ & 1 & 4.0 & & $0.049^{*}$ & 9.333 & $\begin{array}{l}1.05- \\
82.78\end{array}$ \\
\hline \begin{tabular}{|l} 
Allele \\
C
\end{tabular} & $\begin{array}{l}23 \\
27\end{array}$ & \begin{tabular}{|l}
46. \\
0 \\
54. \\
0 \\
\end{tabular} & $\begin{array}{l}30 \\
20\end{array}$ & \begin{tabular}{|l}
60. \\
0 \\
40. \\
0 \\
\end{tabular} & 1.967 & 0.161 & $\begin{array}{l}0.568 \\
1.761\end{array}$ & \begin{tabular}{|l|}
$0.27-$ \\
1.26 \\
$0.79-$ \\
3.89 \\
\end{tabular} \\
\hline
\end{tabular}

$\chi^{2}$ : Chi square test for comparing between the two groups

${ }_{\mathrm{FE}} \mathrm{p}$ : p value for Fisher Exact for Chi square test for comparing between the two groups

OR: Odd`s ratio U.L: Upper limit L.L: Lower limit

C.I: Confidence interval

\section{DISCUSSION}

After several decades of investigations on residual ridge resorption, the perspectives of systemic and local regulation on bone remodeling didn't elucidate great success (2). Previous studies investigated the cause of edentulous jawbone atrophy in the context of bone physiology and pathology, however, results showed great variations under similar circumstances, suggesting a genetic association $(8,26)$.

Genetic variation contributes to virtually every human disease, conferring susceptibility, resistance or interaction with environmental factors. The most common type of genetic variation is the Simple Nucleotide Polymorphism (SNP), where two alternative bases occur at a frequency $(>1 \%)$ in the human population (27). Identification of SNPs in susceptibility genes should enable a better understanding of the mechanisms of disease processes and facilitate the discovery of new and more efficacious treatments for RRR (2).

In 2011, Suwanwela et al conducted a combined study between UCLA \& Manchester universities on fresh and archival DNA samples from various ethnic populations. They studied the genetic association of various single nucleotide polymorphisms in FGFR10P2/wit3.0 gene and long term atrophy of edentulous mandible. The study reported that both SNPs rs840869 and rs859024 minor alleles were associated with severely atrophied mandibles. This study has demonstrated the first indication of a genetic basis to atrophic jaw bone. The outcome of this study immediately suggested a novel genetic diagnostic method to identify patients predisposed to severe atrophy of jaw bone structure (28).

On the year 2012, Jim K et al tried to replicate the results of the previous study and to examine the genetic association between polymorphisms in FGFR1OP2/wit3.0 and residual ridge resorption of mandible in the Korean population. It was found that the minor allele of ss518063493 may be associated with excessive atrophy of edentulous mandible in Koreans (29). However, RRR is a complex phenomenon, other genes related to wound healing after extraction may be involved. Consequently, in 2014, Song J H \& Lee J H studied the relation between various SNPs in the highly polymorphic VEGF gene. There was a notable association with rs1570360 $(P=0.051)$ in dominant group and haplotype A-C-C showed a statistically significant association with RRR in dominant group $(P=0.042)(9)$.

Humans normally have 46 chromosome in each cell, divided into 23 pairs, from here, the name of the famous product "23andMe" -using saliva to provide genetic data to the non health professional cusomer- was derived (30). Chromosome 14 contains about 900 genes that provide instructions for making proteins performing a variety of different roles in the human body, one of these genes is the Hypoxia Inducible Factor-1 $\alpha$ (31). Since HIF-1 $\alpha$ gene is very critical for oral wound healing after extraction of teeth, and since it has a high genetic diversity, in 2015, J Paek et al studied the relation between SNPs in this gene and residual ridge resorption in the Korean population. Statistical analysis of tag SNPs showed that the genetic variation rs11549467 (1790G>A) was associated with the risk of RRR in in dominant and codominant models ( $\mathrm{p}=$ 0.028). Thus, rs11549467 may play an important role in the disturbed bone remodeling balance resulting in RRR (8).

The current study used SNP 1772C $>$ T (rs11549465) that is closely related to the rs11549467 since both are located in exon 12 in the ODD domain of the HIF-1gene (32). The relation between SNP $1772 \mathrm{C}>\mathrm{T}$ and various conditions related to hypoxia -such as cancer and osteonecrosis- has been extensively studied $(10,11,14)$. However, this is the first study to investigate its relation with residual ridge resorption in a sample of the Egyptian population. Consequently, it can be used as a marker to predict the future condition of the alveolar ridge through a simple test based on a saliva sample that can be easily collected in the dental clinic. This can provide the base for developing new diagnostic tools in dentistry that can help to collect genetic data about patients. This would be beneficial before extensive prosthodontic treatment, minimizing failure arising from poor patient selection and reducing costs that arise from mismatched chances for an optimum personalized treatment plan. 
Results showed a predominance of the TT genotype in the patients group. Six cases out of twenty five possessed the homozygous minor allele with percentage of $24 \%$. While in the control group, only one TT genotype was detected out of twenty five with a percentage of $4 \%$. Statisical analysis revealed a $p$-value $=0.049$ indicating a statistical significance for the alternative hypothesis.

In 2015, Paek et al concluded that the prognosis of the alveolar ridge after extraction of the teeth can be predicted using the 1790G $>$ A (rs11549467) as a marker SNP, accordingly, a treatment plan can be set properly decreasing unnecessary expenses (8). Our study can also use the $1772 \mathrm{C}>\mathrm{T}$ (rs11549465) as a marker predicting the future condition of the residual alveolar ridge in the Egyptian population. This can be a new step towards the era of personalized dentistry that emerged recently $(33,34)$. It is a new phase of dentistry using salivary diagnostics and genetic analysis (35). Its aim is to find out biomarkers for periodontitis (36), per-implantitis (37), caries susceptibility (38), oral cancers $(39,40)$ and also predisposition for residual ridge resorption $(8,9,28,29)$.

\section{CONCLUSION}

The present study concluded that there is a significant association between the TT genotype of SNP $1772 \mathrm{C}>\mathrm{T}$ in HIF-1 $\alpha$ gene and the presence of severely resorbed edentulous mandibular ridge. Results of this study may be useful in developing novel genetic diagnostic tests to identify Egyptians susceptible to develop excessive mandibular residual ridge atrophy after dental extraction. However, further researches on larger scales are needed to ascertain the results of this study.

A new phase of personalized medicine and dentistry has already started since completion of The Human Genome projects. Collecting genetic data through saliva-based diagnostic tests will provide the necessary information needed to customize a treatment plan according to the individual needs of each patient. In the future, this information will assist researchers in the tissue engineering field to start gene therapy for oral diseases.

\section{CONFLICT OF INTEREST}

The authors declare that there is no financial or personal relationships with people or organizations that could inappropriately influence the present work.

\section{REFERENCES}

1. Carlsson G. Changes in the jaws and facial profile after extractions and prosthetic treatment. Trans R Sch Dent Stockh Umea. 1967;12:1-29.

2. Nishimura L, Garrett N. Impact of Human Genome Project on treatment of frail and edentulous patients. Gerodontology. 2004;21:3-9

3. Slagter AP, Olthoff LW, Bosman F, Steen WH. Masticatory ability, denture quality, and oral conditions in edentulous subjects. J Prosthet Dent. 1992;68:299-307.

4. Schropp L, Wenzel A, Kostopoulos L, Karring T. Bone healing and soft tissue contour changes following singletooth extraction: a clinical and radiographic 12-month prospective study. Int $\mathrm{J}$ Periodontics Restorative Dent. 2003;23:313-23.
5. Jahangiri L, Devlin H, Ting K, Nishimura I. Current perspectives in residual ridge remodeling and its clinical implications: A review. J Prosthet Dent. 1998;802:224-37.

6. Zarb GA, Hobrick JA, Eckert SE, Rhonda FJ. Prosthodontic treatment for edentulous patients. $13^{\text {th }}$ ed. St Louis: Mosby; 2013. P 48-9.

7. Kim JJ, Shon HC. Chang JH. Kim KS. Lee SW. Kim HIF1 Alpha and VEGF Expression in Fracture Healing. JKOA. 2008;43:479-87.

8. Paek J, Oh Y, Kim J, Lee JH. Single nucleotide polymorphisms in HIF-1 alpha gene and residual ridge resorption (RRR) of mandible in Korean population. Gene Expression. 2015;16:137-44.

9. Song JH, Lee JH. Single Nucleotide Polymorphisms and Haplotypes in Vascular Endothelial Growth Factor Gene and Residual Ridge Resorption of Mandible in Korean Population. J Biomater Nanobiotechnol. 2014;5:39-43.

10. Zhao T, Lv J, Zhao J, Nzekebaloudou M. Hypoxiainducible factor-1 alpha gene polymorphisms and cancer risk: a meta-analysis. J Exp Clin Cancer Res. 2009;28: 159.

11. Li Y, Li C, Shi H, Lou L, Liu P. The association between the rs11549465 polymorphism in the hif- $1 \alpha$ gene and cancer risk: a meta-analysis. Int $\mathrm{J}$ Clin Exp Med. 2015;8:1561-74.

12. Fraga A, Ribeiro R, Coelho A, Vizcaíno JR, Coutinho $\mathrm{H}$, Lopes JM, et al. Genetic polymorphisms in key hypoxia-regulated downstream molecules and phenotypic correlation in prostate cancer. BMC Urol. 2017;17:12.

13. Alidoosti M, Ghaedi M, Soleimani A, Bakhtiyari S, Rezvanfard M, Golkhu S, et al. Study on the role of environmental parameters and HIF-1A gene polymorphism in coronary collateral formation among patients with ischemic heart disease. Clin Biochem. 2011;44:1421-4.

14. Chachami G, Kalousi A, Papatheodorou L, Lyberopoulou A, Nasikas V, Tanimoto $\mathrm{K}$, et al. An association study between hypoxia inducible factor-1alpha (HIF-1 $\alpha$ ) polymorphisms and osteonecrosis. PLoS One. 2013;8:e79647.

15. Cięszczyk P, Eider J, Arczewska A, Ostanek M, LeońskaDuniec A, Sawczyn S, et al. The HIF1A Gene PRO582SER polymorphism in polish power-orientated athletes. Biol Sport 2011; 28: 111-4.

16. Yu ZG, Wang BZ, Cheng ZZ. The association of genetic polymorphisms of hypoxia inducible factor-1 alpha and vascular endothelial growth factor with increased risk of chronic obstructive pulmonary disease: A case-control study. Kaohsiung J Med Sci. 2017;33:433-41.

17. Lin C, Yin G, Ou M, Zheng S. The effects of HIF-1 $\alpha$ and VEGF on wound healing in diabetic mice. Biomed Res. 2017;28:8121-4.

18. Daniel W. Biostatistics. A foundation for analysis in the health science. $6^{\text {th }}$ ed. NY: John Wiley and sons, Inc; 1995.

19. McGarry TG, Nimmo A, Skiba JF, Ahlstrom RH, Smith $\mathrm{CR}$, Koumjian JH. Classification system for complete edentulism. The American College of Prosthodontics. J Prosthodont. 1999;8:27-39.

20. James C, Iwasiow RM, Birnboim HC. Human genomic DNA content of saliva samples collected with the Oragene ${ }^{\circledR}$ selfcollection kit. DNA Genotek Inc 2011. Available at: http://www.dnagenotek.com

21. Kalyanasundaram D, Kim JH, Yeo WH, Oh K, Lee $\mathrm{KH}$, Kim $\mathrm{MH}$, et al. Rapid extraction and preservation of 
genomic DNA from human samples. Anal Bioanal Chem. 2013;405:1977-83.

22. Mendoza ÁC, Volante BB, Hernández ME, Mendoza CC, Pliego AF, Baptista Gonzalez HA, et al. Design of a protocol for obtaining genomic DNA from saliva using mouthwash: Samples taken from patients with periodontal disease. J Oral Biol Craniofac Res. 2016;6:129-34.

23. QIAGEN Supplementary Protocol. Isolation of genomic DNA from saliva and mouthwash using the QIAamp ${ }^{\circledR}$ DNA Blood Mini Kit; vacuum procedure. QIAGEN 2010. Available at: https://www.qiagen.com

24. Kotz S, Balakrishnan N, Read CB, Vidakovic B. Encyclopedia of statistical sciences. $2^{\text {nd }}$ ed. Hoboken, N.J.: Wiley-Inerscience; 2006.

25. Kirkpatrick LA, Feeney BC. A simple guide to IBM SPSS statistics for version 20.0. Student ed. Belmont, Calif.: Wadsworth, Cengage Learning; 2013.

26. QIAGEN Supplementary Protocol. Isolation of genomic DNA from saliva and mouthwash using the QIAamp ${ }^{\circledR}$ DNA Blood Mini Kit; vacuum procedure. QIAGEN 2010. Available at: https://www.qiagen.com

27. Yang Xi, Hong-Cheng Zhu, Chi Zhang, Qin Qin, Jia Liu, Li-Ping Xu, et al. HIF-1 $\alpha 1772 \mathrm{C} / \mathrm{T}$ and $1790 \mathrm{G} / \mathrm{A}$ Polymorphisms Are Significantly Associated with Higher Cancer Risk: An Updated Meta-Analysis from 34 CaseControl Studies. PLoS One. 2013;8:e80396.

28. Suwanwela J, Lee J, Lin A, Ucer TC, Devlin H, Sinsheimer $\mathrm{J}$, et al. A genetic association study of single nucleotide polymorphisms in FGFR1OP2/wit3.0 and longterm atrophy of edentulous mandible. PLoS One. 2011;6:e16204.

29. Kim JH, Oh MY, Paek J, Lee J. Association between FGFR1OP2/wit3.0 Polymorphisms and Residual Ridge Resorption of Mandible in Korean Population. PLoS One. 2012;7:e42734.

30. 23andMe ${ }^{\circledR}$. 2017. Available at: https://www.23andme.com

31. Genetics Home Reference provides consumer-friendly information about the effects of genetic variation on human health. 2017. Available at: https://ghr.nlm.nih.gov.

32. Kim HO, Jo YH, Lee J, Lee SS, Yoon KS. The C1772T genetic polymorphism in human HIF-1alpha gene associates with expression of HIF-1alpha protein in breast cancer. Oncol Rep. 2008;20:1181-7.

33. Schloss AJ, Verjee Z, Spielman The Era of Personalized Dentistry Is Upon Us: It's Time to Include It in Dental Curricula. J Dent Educ. 2017;81:363-5.

34. Kornman KS, Duffy GW. Personalized medicine: will dentistry ride the wave or watch from the beach. J Dent Res. 2012;9(7 Suppl):8S-11S.

35. Tabak LA. A revolution in biomedical assessment: the development of salivary diagnostics. J Dent Educ. 2001;65:1335-9.

36. Giannobile WV, Braun TM, Caplis AK, Doucette-Stamm L, Duff GW, Kornman KS. Patient stratification for preventive care in dentistry. J Dent Res. 2013;92:694-701.

37. Soohyung Lee S, Kim J, Hwang J, Kim S, Lee J , Han D. Investigation of Pathogenic Genes in Peri-Implantitis from Implant Clustering Failure Patients: A Whole-Exome Sequencing Pilot Study. PLoS ONE. 2014;9:e99-360.

38. Zeng Z, Shaffer JR, Wang X, Feingold E, Weeks DE, Lee $\mathrm{M}$, et al. Genome-wide association studies of pit-andfissure- and smooth-surface caries in permanent dentition. J Dent Res. 2013;92:432-7.
39. Scanlon CS, Van Tubergen EA, Inglehart RC, D'Silva NJ. Biomarkers of epithelial-mesenchymal transition in squamous cell carcinoma. J Dent Res. 2013;92:114-21.

40. Van't Veer LJ, Bernards R. Enabling personalized cancer medicine through analysis of gene-expression patterns. Nature. 2008;452:564-70.

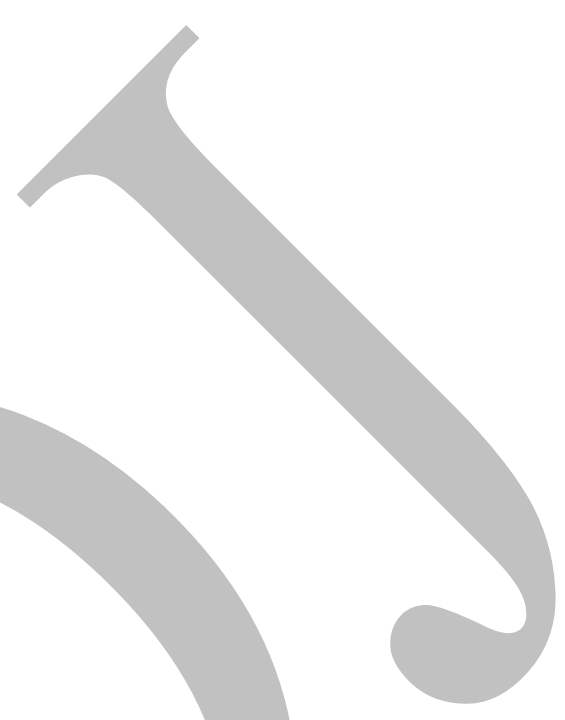

